Alphonse Milne-Edwards, who on some points is the greatest ornithological authority that has ever lived. We are then told of an Oxford undergraduate who "took a walk with his gun in Bagley Wood and brought home fifty different specimens which he carefully stuffed." "He had a museum," it is added, "of several hundreds." We are not told whether this Oxford undergraduate's conduct is worthy of praise or blame, nor would it much signify, for the writer is evidently confused in his notion of "specimens" and "species." To kill specimens of fifty different species in one day and in one wood, though not easy, could no doubt be done in many places, but it would be hard to kill fifty birds that were not different specimens! Would the writer also be surprised to learn that " a museum," or a collection, as people nowadays more humbly style it, "of several hundreds," was some fifty years ago by no means uncommon, and that of late years private collections include not only thousands of specimens, but thousands of species?

But now comes the most astonishing assertion of all. We are told that "Mr. Morris describes more than twelve hundred birds," and that there may be no mistake in the writer's meaning, he subsequently repeats the statement in this wise: "Of the twelve hundred British birds, a good many are represented by a single stray specimen," and so on! The ornithologists of this country have hitherto been deemed by their continental brethren somewhat too hasty in enrolling as "British" every chance waif from foreign lands and seas that has had the ill luck to show itself (and of course be shot) within the limits of the United Kingdom, and we have never understood that on the most liberal interpretation of the expression, "British birds," the number has exceeded four hundred. How blind and inefficient have they been when they have omitted more than two-thirds of the species that occur here! It is really to be hoped that the writer of the leading article on English birds in last Thursday's Times will bring them to a due sense of their neglected duties by furnishing a list of the 800 species whose rights of citizenship have been so shamefully ignored, and if he will at the same time say in which edition of Mr. Morris's work "more than twelve hundred" British birds are described, he will possibly contribute to a more comfortable understanding of the matter, for $\mathrm{Mr}$. Morris has hitherto been supposed to follow very closely the late Mr. Yarrell in the information he gives, so that when the latter in his last edition included 354 species, the former a few years later made the number 358 !

There are many other assertions in the same article which excite a degree of amazement inferior only to the last particularised, and we have heard persons suggest that the writer must have been all the while perpetrating a solemn joke.

\section{EDISON'S ELECTRIC LIGHT}

THE Times New York correspondent gives some interesting details in Monday's paper of Mr. Edison's new form of electric lighting and the steps by which he was led to its discovery. So far the light has withstood every test that has been tried, and so confident do the public seem that success has been attained at last, that the shares of the Edison Company have risen from 20 dollars to 3,500 dollars.

The Philadelphia correspondent of the same journal gives some further information in yesterday's issue. Probably 200 people make up the population of Menlo Park, we are told, nearly all Edison's workmen and their families. He gets an income of 40,000 dollars to 50,000 dollars a year from his various inventions, and he spends it all, the most of it for machinery and wages, and the balance in charity. The correspondent then gives some interesting details concerning $\mathrm{Mr}$. Edison, his habits, his enthusiasm, and his relations with his numerous employés. There is no discipline enforced or any apparent time-table for work, yet with all hands it seems a labour of love, and if you pick out from the crowd the grimiest and most woe-begone of the whole party of overworked alchemists it will be Edison himself. It appears to have been the system at Menlo Park, as with the alchemists of old, to do most of the work at night, and it seems the regular habit of Edison and his chief subordinates to work straight through the twenty-four hours without stopping, until tired nature compels them to drop down in any handy place and go to sleep. "We went there," the correspondent writes, "hoping that Edison had succeeded, but nevertheless sceptics, and we came away thorough believers. His lamps were burning when we arrived, and they burnt continuously until our departure, excepting from half-past four to half-past five P.M., when about an hour's time was taken in putting in a new generator to do the work, which be had just finished and desired to try. During the daylight we could see the lamps burning, supplied by the first generator, and perceived that the little carbon loop or horseshoe giving the light remained intact. After dark, when the second generator went to work, we saw for three hours the lamps successfully burning as a complete substitute for gas for every purpose for which illumination was necessary at Menlo Park. The gas jets were idle, being put out of use by the steadier and more genial glow of the electric light. We ate our supper by it in the little restaurant that has been established at the Park, and I sat down in Edison's office under two of his lamps attached to a gas bracket and wrote the rough draft of the telegram sent to the Times. In this room a telegraph operator worked in a corner with an Edison lamp in a movable table stand illuminating his work. Down stairs his bookkeeper was paying off the hands by the aid of two more electric lights on a gas bracket. Out in the roadway in front of the building two street lamps were set up with the Edison light in full operation. In his workshop the engineer was running his engine and a couple of men watching the operation of the new generator by the light of more Edison's lamps, while in the laboratory some fifteen of them were giving light for various operations, and downstairs a young man sat at the regulator, and, watching another light, by the aid of the galvanometer, kept the flame steady, just as the regulator is worked constantly in the gas-house to adjust the gas pressure, so that it will compensate for turning lights on or off throughout the town. It was between seven and eight o'clock on a dark winter evening, and the electric light had put into disuse both the gas jets and the petroleum lamps that were in profusion around. I visited four dwellings in the village and saw the Edison lamps doing the work of illumination for all household purposes in each of them. In Edison's own house, where he had at least a dozen of them, we remained over half an hour, and I shall never forget the glee with which Edison listened to the reading of a newspaper slip, wherein an ambitious ' expert' offered to forfeit roo dollars for every lamp that Edison could keep burning over twenty minutes."

\section{NOTES}

ON Friday, the 9th inst., the St. Andrew's University Court agreed to report to the Queen in Council in favour of an application by Prof. Swan to be permitted to retire, on the ustal retiring allowance, from his Chair of Natural and Experimental Philosophy in the University, on the ground of failing health.

Mr, E. W. Cooke, R.A., F.R.S., whose death at the age of sixty-nine years, took place at Groombridge on the $4^{\text {th }}$ inst., deserves some notice in these pages for his connection in various ways with science. From his boyhood he had the keenest interest in natural history, and was probably one of the first amateur horticulturists. He was connected with most of our scientific societies, and was an early member and constant 